\title{
Carrot seed germination in different conditions of salinity and temperature
}

\author{
Germinación de semillas de zanahoria en diferentes condiciones \\ de salinidad y temperatura
}

\author{
Maristela Aparecida Dias ${ }^{1}$, José Carlos Lopes ${ }^{2}$, Gustavo Augusto Moreira Guimarães ${ }^{1 *}$, \\ José Dias de Souza Neto ${ }^{3}$, Carolina de Oliveira Bernardes ${ }^{2}$
}

\begin{abstract}
The success of the germination process depends on the entry of water through the tissues that enclose the embryo. The presence of salts reduces the gradient between the ground and the surface of the seed, restricting the absorption of water by the seed. The objective of the experiment was to evaluate the effect of salinity and temperature on the germination of carrot seeds. The osmotic potentials utilized in the solutions were 0.0 (control); $-0.4 ;-0.8 ;-1.2,-1.6$ and $-2.0 \mathrm{MPa}$. obtained with the use of $\mathrm{NaCl}$ p.a.; the temperatures used were $15^{\circ} \mathrm{C}, 20^{\circ} \mathrm{C}, 25^{\circ} \mathrm{C}, 35^{\circ} \mathrm{C}, 15-35^{\circ} \mathrm{C}$ and $25-35^{\circ} \mathrm{C}$. A commercial variety of carrot seeds, the 'Brasilia' cultivar, was used. Percentage germination, germination speed index, fresh and dry mass of seedlings were determined. The averages were subjected to analysis of regression. Germination was reduced by the temperature of $35^{\circ} \mathrm{C}$ and by osmotic potentials greater than $-0.8 \mathrm{MPa}$. Temperatures of $20^{\circ} \mathrm{C}$ and $25^{\circ} \mathrm{C}$ are more favorable to the germination of seeds in the GSI salt conditions tested.

Key words: Daucus carota L., Germination, Seed, Salinity.
\end{abstract}

\section{RESUMEN}

El éxito en el proceso de la germinación depende del agua que ingresa a través de los tejidos que rodean la semilla. La presencia de sal reduce el gradiente entre el suelo y la superficie de la semilla, lo que limita la absorción del agua por la semilla. El objetivo de la investigación fue evaluar el efecto de la salinidad y la temperatura sobre la germinación de semillas de zanahoria. El potencial osmótico utilizado en las soluciones fue 0,0 (control); - 0,4; -0,8; -1,2, -1,6 y 2,0 Mpa, obtenidas con el uso de NaCl, y las temperaturas utilizadas fueron $15{ }^{\circ} \mathrm{C} 20^{\circ} \mathrm{C} 25^{\circ} \mathrm{C} 35^{\circ} \mathrm{C} 15-35^{\circ} \mathrm{C}$ y $25-35^{\circ} \mathrm{C}$. En las evaluaciones, se utilizó un lote comercial de Brasilia. En las evaluaciones de semillas de zanahoria cv se midieron porcentaje de germinación, índice de velocidad de germinación, peso fresco y seco de las plántulas. Las medias fueron sometidos a análisis de regresión. En el ensayo, la germinación se redujo en $35^{\circ} \mathrm{C}$ en potencial osmótico mayor que -0,8 MPa. Las temperaturas de $20^{\circ} \mathrm{C}$ y $25{ }^{\circ} \mathrm{C}$ son más favorables para la germinación y la tasa de germinación de las condiciones ensayadas.

Palabras clave: Daucus carota L., germinación, la semilla, la salinidad

\section{Introduction}

The degree of salt tolerance varies among species, with the stage of plant development as well as with environmental factors such as soil fertility, irrigation and climate, experiencing a reduction in output from excess soil salinity (Tanji and Kielen, 2002; Fontes, 2005). The level of sensitivity of plants to salt stress is controlled by translocation, absorption and exclusion of ions of sodium and chlorine. Water and temperature are external factors that interfere with the germination process (Ferreira et al., 2001; Cavatte et al., 2004; Marcos Filho, 2005).

Germination success depends on water movement through the tissues surrounding the embryo. This movement is related to the water potential in the region around the seeds and the soil water potential, which promotes a gradient of potential and can restrict water uptake by seeds, interfering directly with the germination process. When the osmotic potential of the solution is more negative than that of the by cells of the embryo

\footnotetext{
Instituto Federal Goiano. Iporá, Goiás, Brasil.

Universidade Federal do Espírito Santo. Alegre, Espírito Santo, Brasil.

Instituto Federal do Espírito Santo. Alegre, Espírito Santo, Brasil.

* Autor para correspondência: gustavo.guimaraes@ifgoiano.edu.br
}

Fecha de Recepción: 13 Febrero, 2015.

Fecha de Aceptación: 1 Septiembre, 2015. 
germination occurs (Cavalcante and Perez 1995, Carvalho and Nakagawa, 2000).

In regions that can accumulate large amounts of salt, as in depressions where the aquifer is high in poorly drained areas and those heavily irrigated areas where there is a considerable amount of salt in irrigation water, as can be seen in intensive vegetable crops (Larcher, 2003). Under these conditions the germination and development of seedlings can be compromised as a result of the difficulty of absorption of water and the entry of toxic ions, which reduce water absorption and modify the soaking process (Klar, 1984). Temperature, in turn, is the factor that interferes with the rate at which processes occur; it can accelerate the effects of salt stress (Marcos Filho, 2005).

The carrot (Daucus carota L.) is native to Europe and Asia, emerging as one of the most traditional vegetables consumed in Brazil (Vieira and Makishima, 2005). The variety most planted in Brazil is 'Brasilia' cultivar; good adaptation to Brazilian conditions makes its rapid expansion possible (Vieira et al., 2000).

The objective of this study was to evaluate the effect of temperature and salinity on the germination potential of carrot cultivar Brasilia.

\section{Material and Methods}

The study was performed in the Laboratory of Technology and Seed Analysis of the Center for Agricultural Sciences, Federal University of Espírito Santo, in Alegre, Espírito Santo, Brazil. Carrot seeds (Daucus carota L.), cultivar 'Brasilia' were used in the studies. The seeds were sown in germination paper, soaked in sodium chloride $(\mathrm{NaCl})$ prepared according to the Van't Hoff equation (Salisbury and Ross, 1992) at concentrations of 0.0 (control) $-0.4-0.8,-1.2,-1.6$ and $-2.0 \mathrm{MPa}$. The amount of solution used was equivalent to 2.5 times the dry paper weight in accordance with what has been recommended by the Brazilian rules for seed testing (Brasil, 2009). The treatments consisted of four replicates of 50 seeds, which are formed by wet paper rolled towels moistened with distilled water and kept in BOD (Biological Oxygen Demand) in conditions of constant temperature of $15^{\circ} \mathrm{C}, 20^{\circ} \mathrm{C}$, $25{ }^{\circ} \mathrm{C}$ and $35^{\circ} \mathrm{C}$ and alternating temperature of $15-35{ }^{\circ} \mathrm{C}$ and $25-35^{\circ} \mathrm{C}$. Alternate temperatures were achieved by adjusting the equipment, with 8 hour photoperiod supplied at higher temperature to simulate the conditions of the day and 16 hours of darkness provided with lower temperature conditions simulating the night.

The evaluations were performed daily and the seeds were considered germinated when they presented the primary root protruded two millimeters or more. We used the Maguire formula (Maguire, 1962) to calculate the germination speed index (GSI). After 14 days of germination, percentage of normal seedlings (germination), fresh and dry weight of seedlings were determined. Analyses were carried out in a completely randomized design and the results were subjected to regression analysis.

\section{Results and Discussion}

At all tested temperatures the germination percentage was reduced proportionally to the increase of the substrate saline concentration; the interaction was due to the temperature of $35^{\circ} \mathrm{C}$ (Figure 1). The increase of the saline concentration in the solution, making the potential more negative with values inferior to - $0.4 \mathrm{MPa}$ produced a significant reduction in seed germination capacity. This behavior of the carrot seeds suggests their sensitivity to the increase in the saline concentration of the medium, due to the toxic effect of $\mathrm{NaCl}$ which promoted reduction of germination. Secco et al. (2010) working with different cultivars of melon plant also verified the deleterious effect of the salt concentration on the germination of this species from -0.4 MPa saline concentration. Henicka et al. (2006) evaluating the effect of saline stress promoted by $\mathrm{NaCl}$ in Apuleia leiocarpa seeds verified that up to -0.4MPa there was no effect of the salinity upon the germination process.

Observation of the germination behavior of a species in a saline environment provides information about the tolerance of the plants to the excess of salt (Dickmann et al., 2005; Lima e Torres, 2009), since salinity negatively affects the growth and development of plants. The observation of the germination behavior of one species regarding a control treatment is an indication of the tolerance index of the species to salinity (Góis et al., 2008).

The results obtained for carrot seeds in this study also agree with those of other species por Braga $e t$ al., 1999, Fonseca and Perez, 2001, Yamashita et al. 2009 and Guedes et al., 2011 for bean seeds, Adenanthera pavonina, Chorisia glaziovii O. Kuntze and Chaptalia nutans, respectively. 


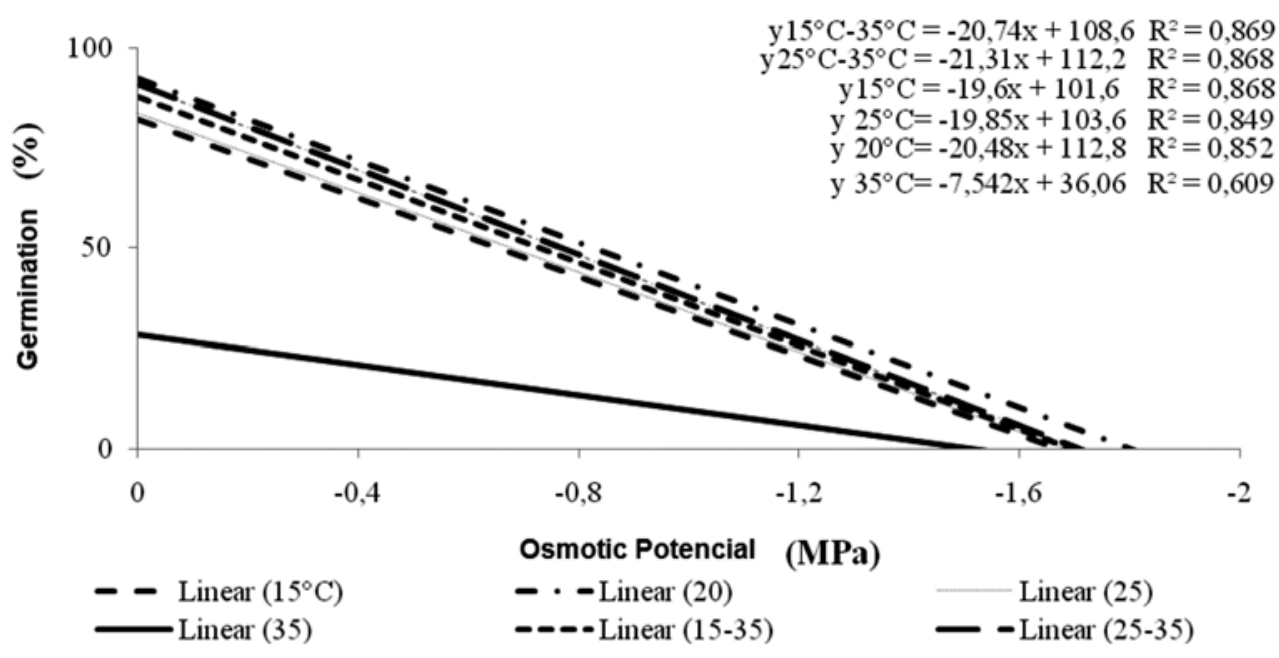

Figure 1. Germination percentage of carrot seeds submitted to different temperatures and osmotic potentials.

Seeds that were germinated under a temperature of $35^{\circ} \mathrm{C}$ had the lowest percentage values of germination in all the saline concentrations evaluated, indicating the negative effect of this temperature on the germination of carrot. According to Marcos Filho (2005), germination occurs in determined temperature limits, with an optimum temperature. Temperatures greater than this may compromise enzymatic system activities, interfering in the several metabolic processes of germination. According to the rules for seed analyses, the most favorable temperature for the germination of carrot seeds is $20^{\circ} \mathrm{C}$ (Brasil, 2009). It is also observed that at other temperatures the reduction in germination occurs as a consequence of the increase of salt concentration in the substrate, and the process is completely inhibited in water potentials less than than $0.8 \mathrm{MPa}$. This result is justifiable, because high salt concentration of is one stress factor for the plants (Taiz and Zeiger, 2004; Marcos Filho, 2005).

Seed vigor, evaluated by the germination speed index (Figure 2), indicated that the increase in temperature associated with the reduction of the osmotic potential of the medium reduced the germination speed of carrot seeds. At the temperatures of $15^{\circ} \mathrm{C}$ and $15-35^{\circ} \mathrm{C}$ there was significant reduction in seed vigor with the reduction of the osmotic

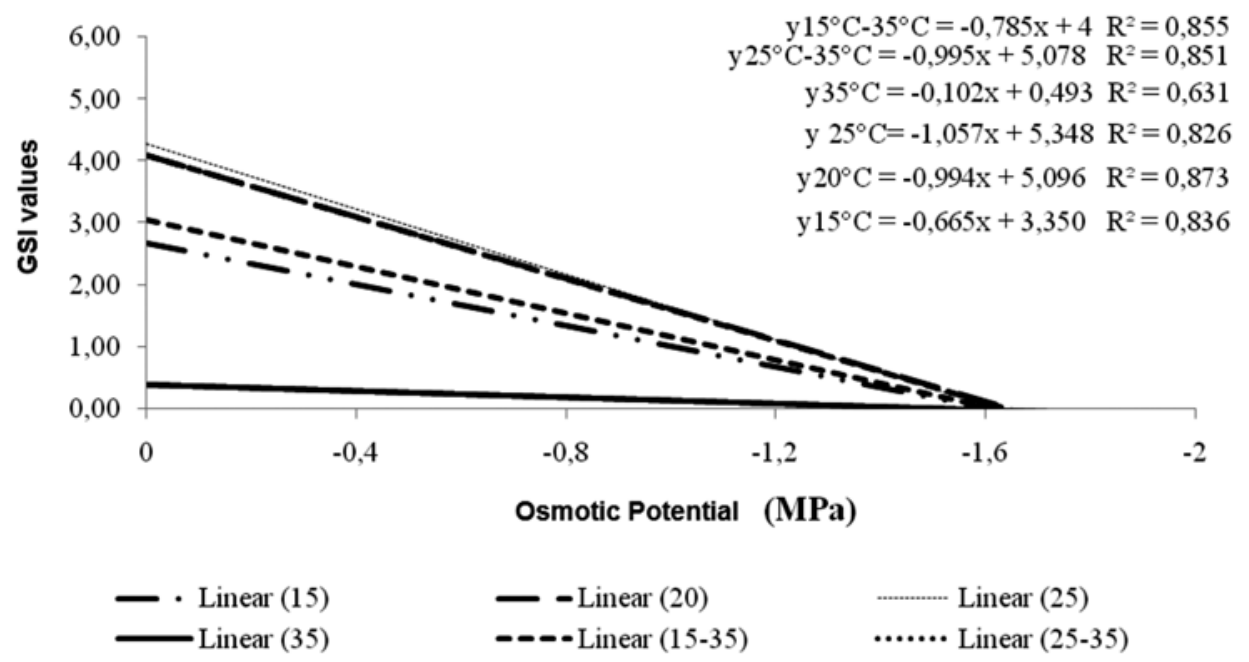

Figure 2. Germination speed index (GSI) of carrot seeds submitted to different temperatures and osmotic potentials. 
potential of the medium. At $35^{\circ} \mathrm{C}$ the lowest values of germination speed were observed, independent of the tested saline concentration. Considering that in absence of the other limiting factors germination may occur in a wider temperature amplitude (Carvalho and Nakagawa, 2000), a more expressive toxic effect is observed of $\mathrm{NaCl}$ upon carrot seed germination speed at the temperatures of $15{ }^{\circ} \mathrm{C}$, $35^{\circ} \mathrm{C}$ and alternated $15-35^{\circ} \mathrm{C}$.

The results illustrated in Figure 3 suggest that the formation of fresh mass by the carrot plants was directly affected by the reduction of the solution potential, possibly by the restriction of water entrance in the cells, restraining their development. Another factor that may have contributed to this result would be the reduction in enzymatic activity as a consequence of the reduction in the external water potential. The accumulation of dry mass (Figure 4) decreased in proportion to saline concentration, and there was no significant variation among the temperatures of $25-35{ }^{\circ} \mathrm{C}, 25{ }^{\circ} \mathrm{C}$ and $20{ }^{\circ} \mathrm{C}$. To evaluate the degree of stress suffered by the plant and its capacity to overcome saline stress, biomass production and growth rate are efficient points to
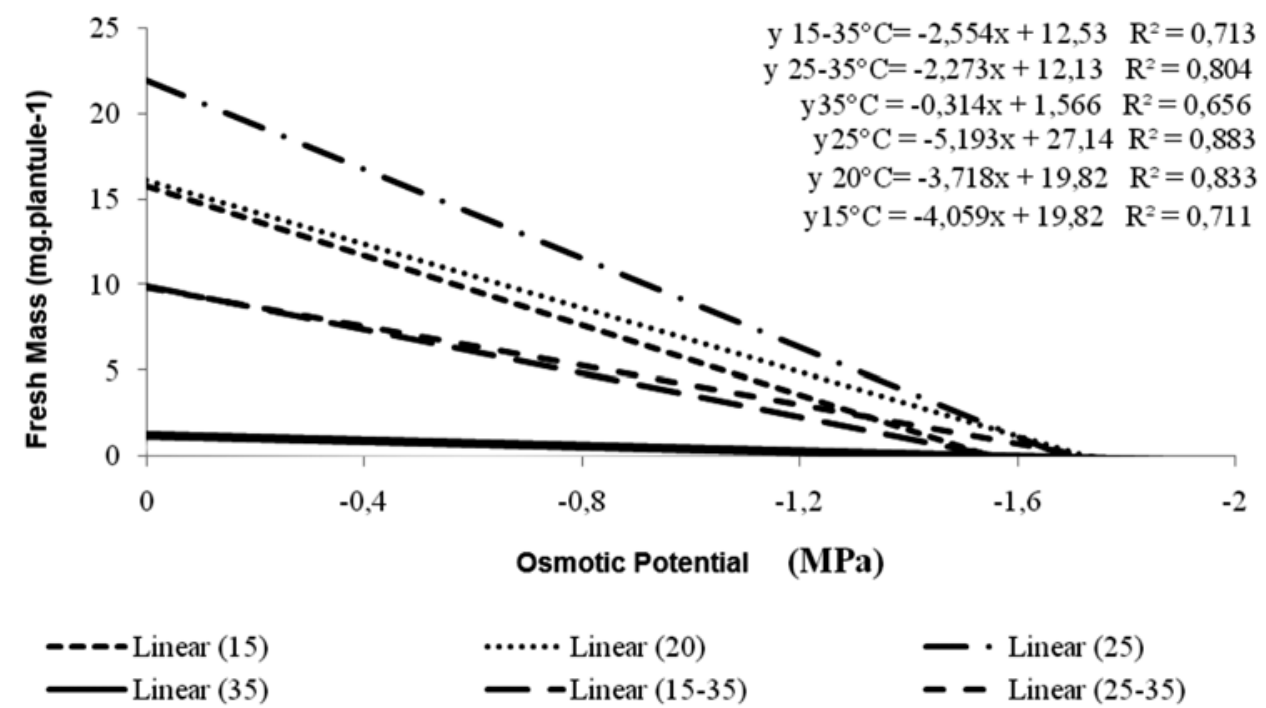

Figure 3. Carrot seedling fresh mass (mg.plant-1) obtained from seeds submitted to different temperatures and osmotic potentials.1. (distilled water); 2. (-0.4 MPa); 3. (-0.8 MPa); 4. (-1.2 MPa); 5. (1.6 MPa); 6. (-2.0 MPa).
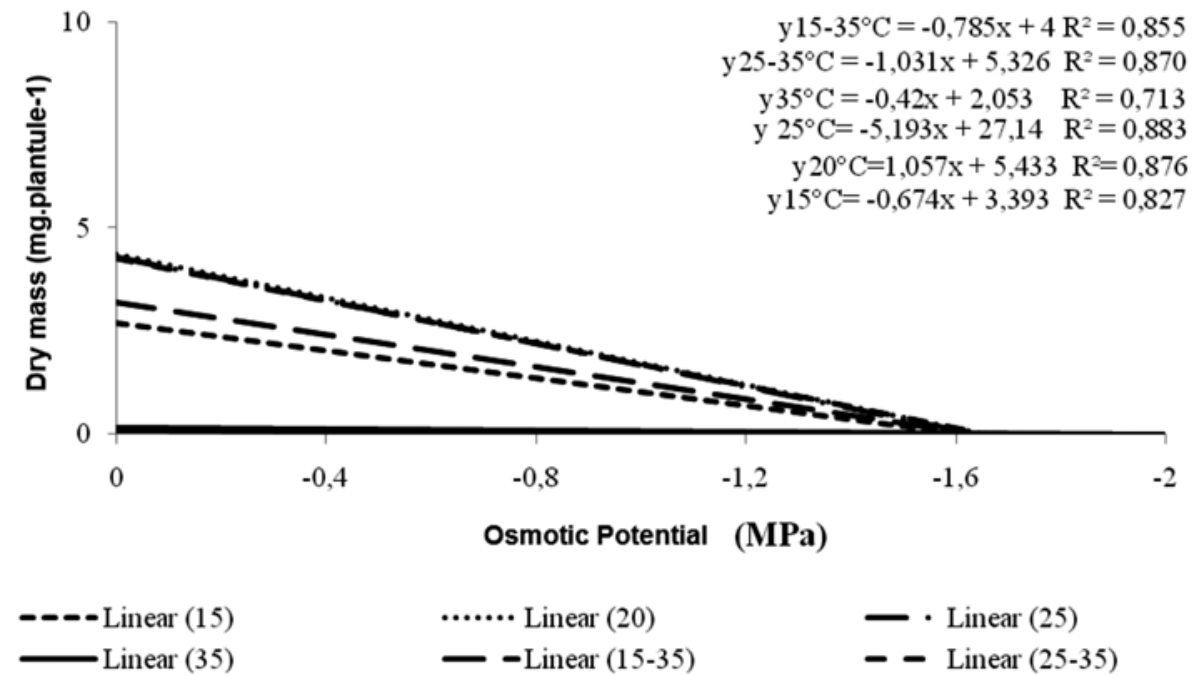

Figure 4. Carrot seedling dry mass (mg.plant $\left.{ }^{-1}\right)$ obtained from seeds submitted to different temperatures and osmotic potentials. 
indicate the effects of salt on its development. As well as constituting an indispensable factor for germination, water is directly or indirectly involved in the several stages of subsequent metabolism, and its presence is indispensable for the enzymatic reactions, solubilization and metabolite transport, as well as acting on the digestion of the energetic reserve of the seeds (Carvalho and Nakagawa, 2000).

According to Perez and Moraes (1994), seedling growth inhibition determined by salinity is due not only to salt toxic effects, but also to the physiological drought produced. When there is an increase in the salt concentration of the soil there is a reduction in the osmotic potential and consequently lowering of the water potential, and it may affect water absorption kinetics by the seeds (osmotic effect), as it may also elevate the concentration of toxic ions to the embryo (toxic effect). The salt excess acts on cell metabolism, interfering with the cell expansion process, limiting wall elasticity and consequently plant growth (Taiz and Zeiger, 2004).

\section{Conclusions}

The increase of saline concentration in the substrate reduces the germination potential of carrot seeds, especially at a temperature of $35^{\circ} \mathrm{C}$.

The saline stress produced by $\mathrm{NaCl}$ over -0.4 Mpa potential negatively affected the germination development of the carrot seeds.

Temperatures of $20^{\circ} \mathrm{C}$ and $25{ }^{\circ} \mathrm{C}$ are more favorable to the germination of seeds and the GSI salt conditions tested.

\section{Acknowledgements}

To the Federal University of Espírito Santo State-UFES.

\section{Literature Cited}

Braga, L.F.; Sousa, M.P.; Braga, J.F.; Sá, M.E.

1999. Efeito da disponibilidade hídrica do substrato na qualidade fisiológica de sementes de feijão. Revista Brasileira de Sementes, 21: 95-102.

Brasil. Ministério da Agricultura e Reforma Agrária. 2009. Regras para análise de sementes, Brasília. 399 p.

Carvalho, N.M.; Nakagawa, J.

2000. Sementes: ciência, tecnologia e produção. Universidade Estadual Paulista, Jaboticabal. 587 p.

Cavalcante, A.M.B.; Perez, S.C.J.G.A.

1995. Efeito do estresse hídrico e salino sobre a germinação de sementes de Leucaena leucocephala (Lam) de Wit. Pesquisa Agropecuária Brasileiras, Brasília, 30: 281-289.

Cavatte, P.C., Lopes, J.C.; Lima, E.A.

2004. Efeito do estresse salino e da temperatura na germinação, no vigor de sementes e no desenvolvimento de plântulas de tomate. Viii Encontro Latino Americano De Iniciação Cientifica, 562-564.

Dickmann, L.; Carvalho, M.A.C., Braga, L.F.; Sousa, M.P. 2005. Comportamento de sementes de girassol (Helianthus aпnии L.) submetidas a estresse salino. Revista de Ciências Agro-Ambientais, Alta Floresta, 3: 64-75.

Ferreira, R.G., Tavora, F.J.A.F.; Hernandez, F.F.F.

2001. Distribuição da matéria seca e composição química das raízes, caule e folhas de goiabeira submetida a estresse salino. Pesquisa Agropecuária Brasileira, 36; 79-88.

Fonseca, S.L.C.; Perez, C.J.G.A.

2001. Germinação de sementes de olho-de-dragão (Adenanthera pavoniana L.): ação de poliaminas na atenuação do estresse salino. Revista Brasileira de Sementes, 23: 14-20.

Fontes, P.C.R.

2005. Olericultura: teoria e prática. Universidade Federal de Viçosa, Viçosa. 486p.
Góis, V.A.; Torres, S.B.; Pereira, R.A.

2008. Germinação de sementes de maxixe submetidas a estresse salino. Revista Caatinga, 21: 64-67.

Guedes, R.S.; Alves, E.U.; Galindo, E.A.; Barrozo, L.M.

2011. Estresse salino e temperaturas na germinação e vigor de sementes de Chorisia glaziovii O. Kuntze. Revista Brasileira de Sementes, 33: 279-288.

Henicka, G.S.; Braga, L.F.; Sousa, M.P.; Carvalho, M.A.C. 2006. Germinação de sementes de Apuleia leiocarpa (vogel.) j. f. macbr.: temperatura, fotoblastismo e estresse salino. Revista de Ciências Agro-Ambientais, Alta Floresta, 4: 37-46.

Klar, A.E.

1984. A água no sistema solo-planta-atmosfera. São Paulo. $408 \mathrm{p}$.

Larcher, W. 2003. Physiological plant ecology, Berlin. 513 p.

Lima, B.G.; Torres, S.B.

2009. Estresses hídrico e salino na germinação de sementes de Zizyphus joazeiro Mart. (Rhamnaceae). Revista Caatinga, 22: 93-99.

Maguire, J.D.

1962. Speed of germination-aid in selection and evaluation for seeding emergence and vigor. Crop Science, Madison, 2: 176-177.

Marcos Filho, J.

2005 Fisiologia de sementes de plantas cultivadas. Escola Superior de Agronomia Luiz de Queioz, Piracicaba. 495 p.

Perez, S.C.J.G.A.; Moraes, J.A.P.V.

1994. Estresse salino no processo germinativo de algarobeira e atenuação de seus efeitos pelos reguladores de crescimento. Pesquisa Agropecuária Brasileira, 29: 389-396.

Salisbury, F.B.; Ross, C.W.

1992. Plant physiology. Wadsworth Publishing Company, California. 628 p. 
Secco, L.B.; Queiroz, S.O.; Dantas, B.F.; Souza, Y.A.; Silva, P.P. 2010. Germinação de sementes de melão (Cucumis melo L.) em condições de estresse salino. Revista Verde, 4: 129-135.

Taiz, L.; Zeiger, E.

2004. Plant physiology, Sunderland. 719 p.

Tanji, K.K.; Kielen, C.K.

2002. Agricultural Drainage Water Management in Arid and semi-arid areas. Davis: FAO, 135-160 p. (FAO irrigation and drainage paper, 61).

Vieira, J.V., Makishima, N.

2005. O Cultivo da cenoura Embrapa Hortaliças. < http:// www.cnph.embrapa.br/paginas/sistemas_producao/ cultivo_da_cenoura.htm > consultado: 01/Dic/ 2014.

Vieira, J.V.; Ritschel, P.S.; Charcar, J.M.; Lana, M.M.; Lima, D. de B.; Lopes, C.A.; Moita, A.W.

2000. Melhoramento de cenoura para regiões tropicais. BioTecnologia, 16: 18-21.

Yamashita, O.M; Guimarães, S.C.; Albuquerque, M.C.F.; Carvalho, M.A.C.; Silva, J.L.

2009 Efeitos de fatores ambientais induzidos na germinação de sementes de Chaptalia nutans (L.) Polack. Revista Brasileira de Sementes, 31: 132-139. 